\title{
Caring for Unclean Animals in Ancient Israel: An Ecological Perspective
}

\author{
Daniel Berchie \\ Valley View University
}

\begin{abstract}
In view of the biblical kosher law of clean and unclean animals, the question of whether unclean animals could be reared or not in Ancient Israel becomes an ecological concern (Lev. 7:21; 11:26) for religious bodies today who still consider certain animals as unclean. A theological study of the law in the Pentateuch suggests that, in Ancient Israel, unclean animals were well catered for. Physical contact with live unclean animals did not render one unclean. Rather, uncleanness could be acquired through the touching of the carcass of clean or unclean animals (11:24-28, 38-39). As part of their stewardship ordained by God (Gen. 1:26), the people of Israel touched and reared/cared for unclean animals. Amongst other things, analysis of Gen. 1:26, in the Hebrew text, indicates that the primary purpose of human creation, as cosmic stewards over all creatures (including unclean animals), is underlined. Hence, contemporary religious bodies, who still consider certain animals as unclean, should have an unfeigned care and positive attitude towards all unclean animals.
\end{abstract}

Keywords: unclean animals, Stewards, socio-ecological, kosher (“kashrut”), theo-Ecocentric, Ancient Israel

\section{Introduction}

Over the last two decades, both Jewish and Christian environmental ethicists and ecologists have challenged the anthropocentric view imposed by critics on biblical data (White 1976; Rockefeller and Elder 1992; Nash 1996; Bernstein 1998; Hiers 1996-1998). This criticism may have occasioned the Jewish environmental movement, whose objective is to showcase how ecological Jewish religion is (Katz 1994; Schwartz 1995; Tirosh-Samuelson 2001) and how its beliefs have been consistent with environmental protection (Tirosh-Samuelson 2001). The discussion has been topical, presenting the general attitude of Jews and Christians to the environment (Tirosh-Samuelson 2001). In an attempt to reconcile anthropocentrism and ecocentric-Jewish ecology, David Vogel is very succinct when he says, "the Jewish tradition holds that, while humans do have responsibilities for animals, these responsibilities should not come at the expense of human welfare ... in short, in Judaism, nature does not have rights; rather humans have responsibilities for the natural world" (Vogel 2001).

Vogel (2001) draws on ancient and medieval Jewish texts to demonstrate how nature should be responsibly enjoyed and preserved. References to good treatment of animals in general are cited, yet he contends that the "kashrut" laws, which distinguish between foods to be eaten and not to be eaten, have nothing to do with animal protection. He continues that, as made clear in the book of Job, certain creatures have no use

Daniel Berchie, Ph.D., School of Theology and Missions, Valley View University, Ghana; main research field: New Testament Interpretation. Email: sperger123@yahoo.com. 
to humans (Vogel 2001). While Vogel and others have attempted to react forcefully to the criticism of Judeo-Christian insensitivity to the environment in general terms, especially when it comes to treatment of animals, the socio-ecological stance toward unclean animals in the biblical data and other Jewish writings has received little attention (Brin 1977; Lobban 1994). The question of whether unclean animals, particularly domestic ones, had a place in ancient Israel's ecological strata has not been adequately studied. The study becomes necessary looking at the "Pig Law of 1962," which made raising of pigs in Israel untotemic or abhorrent even until today (Diener and Robkin 1978; Lobban 1994; Barak-Erez 2007).

The purpose of this study is to ascertain: (1) the place of the unclean animals in ancient Israel's socio-ecological economy; (2) the impact of the "kashrut" laws on unclean animals in the ecological concerns of the time; and (3) whether Jews cared for unclean animals or not. To this end, a theological study of the place of unclean animals, in both the antediluvian and postdiluvian stages, is conducted. Since Israel's history is incomplete without the antediluvian story, tracing the place of unclean animals in the antediluvian world may be theologically sound. Also, a survey of the Jewish relationship to unclean domestic animals in the "kashrut" laws is carried out. These form the trajectory of this study.

\section{Unclean Animals in Antediluvian Stage}

The antediluvian world begins with the creation of heaven and earth. God is said to have created everything in six days (Gen. 1:1-31). In order of creation, terrestrial creatures and human beings were all created on the sixth day. All of them were created from the dust (v. 24) and "everything that God had made from the first to the sixth day was good." God admired and regarded His own creation as meeting His standards.

Humanity, though created from the dust and on the sixth day, as were other earthly creatures, was made in the image of God (v. 26). The form of humankind may be a symbolic reference to God's presence on earth, whose intelligence is higher than other creatures (Waltke and O'Connor 1990). The key here is God's assignment for humans to rule God's terrestrial creation (v. 26). It reads, "then God said, let us make man in our image, in our likeness, and let them rule over the fish of the sea and the birds of the air, over the livestock, over all the earth, and over all the creatures that move along the ground" (New International Version 1984). The verb " $n$ 'sh," meaning "let us make," is cohortative. The verb that follows " $n$ 'sh" is "wyrdu" (imperfect tense, 3rd person masculine plural). "Yrddu" is prefixed by "waw" conjunctive $\left(w^{e}\right)$ and it literally means "and let them rule” (Waltke and O’Connor 1990). When used this way, the verb that follows the cohortative usually expresses purpose or result of the verb in the cohortative. If so, the syntax suggests the purpose or result of human creation (Gen. 19:20; 34:232; Sam. 3:21). The context suggests that the purpose of human creation was to rule God's creation and the result was that they obeyed in caring for the garden and the naming of animals (2:15, 19-20a). The word "rule" is the Hebrew translation of "rdh." It is used 25 times and can mean "to thread" (e.g., Joel 4:13), "to scrape out” (e.g., Judges 14:9), or simply "to rule” or "govern” (e.g., Psalms 72:8; Hollayday 1971). When it is used with governance, it may have a variety of meanings in terms of its force. For example, when an Israelite becomes master over another Israelite, his treatment of the hired servant should not be inhumane (e.g., Lev. 25:43, 46). The hired servant is owned by God, not the master. The duty of the master is to properly and ethically oversee what belongs to God. But in the context where the people of Israel are subject to the rule of enemy state, cruel treatment is envisaged (e.g., 26:17). Particularly, a divinely ordained rule is shaped with specific responsibility and accountability (Lev. 25:43; 1 Kings 3:1-4). This rule does not warrant 
abuse of office and responsibility. In the creation context, human and other creatures are not set against each other as enemies. It was a scene without strife and competition. In this serenity, ruling with responsibility and accountability may be in view.

In an attempt to respond to the misreading and misapplication of Gen. 1:26-28, as an indictment of Judeo-Christian environmental ethics, Richard H. Hiers sharply argues that:

Only the aboriginal man and woman were authorized to subdue the earth and have dominion. Moreover, everything in Genesis 1 preceded the time of the great flood (Gen. 6-9), after which the whole structure of relations among humans, other creatures, and God was altered radically. It, therefore, seems that these commands were understood to have applied only to conditions during that antediluvian era. (Hiers 1996-1998)

It is fair to say that the charge to multiply and fill the earth is again given to humans $(9: 1,7)$. The statement "rule the earth," in strictest sense, does not appear in this charge, as in the creation story. Though not a legal requirement, God pronounces the fear of human on all living creatures on earth (v. 2). The Hebrew word "môr" meaning "fear" or "terror", used in this verse, may mean emotional fear (Deut. 5:5), the fear of evil befalling someone (Gen. 31:31), reverence or awe (Lev. 19:3), righteous behaviour or piety (Lev. 19:14; 2 Kings 17:34), and formal religious worship (Deut. 31:11-12) (Brown et al. 1952). The already existing relationship between the one fearing and the one feared may provide a framework for the future operation of divine intent, for example, as God said (Exod. 20:12), a child is to fear/revere the parents, because they gave birth to him/her. The people of Israel are to fear/worship God, because He fulfilled His promise and saved them from Egypt (v. 2). The already existing relationship between human and other creatures may also be assumed here. The human being is still the image of God after the flood (Gen. 9:6). The crowning of humans as the stewards of God's other creatures in the creation story (1:26-29) may define this already existing relationship, sanctioned by God. This may indicate that humans are still the head of the ecological order after the flood. The "fear", in this socio-ecological relationship, may be the recognition of humans as higher than other living creatures, as it was in the creation story (Hiers 1996-1998). This recognition can be conceptually termed "human stewardship" as God said (Exod. 20:12; Tirosh-Samuelson 2001). In short, "rhd" and "môr" may point to one meaning of stewardship, in the context of the socio-ecological framework of theo-ecocentric order.

In the next section, the concept of animal uncleanness in kosher law is considered. It intends to present what makes an animal unclean.

\section{Animal Uncleanness in the Kashrut Laws}

The designation of some animals as being unclean and others clean is first found just prior to the flood (Gen. 7:2). This distinction between clean and unclean animals further appears in the divinely ordained dietary laws for Israel (Lev. 11; Deut. 14). Several positions have been taken, regarding the rationale behind this distinction (Douglas 1966; Milgrom 1990; Hasel 2005; Firmage 2008). Inquiry into the rationale for the "kashrut" laws falls outside the purview of this study. However, a distinction which antedates the institution of "kashrut" laws in Israel's history may help identify the place and value of unclean animals.

In the creation story, no mention is made of any distinction between clean and unclean animals. Living creatures, other than human, are taxonomically classified as sea, air, or land animals (Gen. 1:21, 25). The Hebrew word "bhmh", which KJV usually translates as "cattle", in the creation story and afterwards, may be a general reference to four-footed land animals, as distinct from sea and air creatures (Brown et al. 1952). In Genesis, the mention of sheep ("tsôno"), oxen ("bkr"), asses ("chmôr"), and camels ("gml”) are references to 
some specific earthly four-footed animals (e.g., 4:2; 12:16). All these four-footed animals are classified as "bhmh." This suggests that these four-footed animals were all considered earthly beasts that were all created by God.

In the flood story, "bhmh" consists of clean and unclean animals (7:2). The Hebrew form of clean is "thwr" and this word occurs not less than 90 times in the Hebrew Bible (hereafter referred to as HB). It is usually used cultically, morally, or in physical sense of "fineness" (v. 2; 8:20; Exod. 25:11f; Hab. 1:3; Holladay 1971). Its antonym is the Hebrew adjective "tm" meaning "unclean", and it is used more than 50 times (Brown et al. 1952). It is also used ethically, cultically, and topographically (Brown et al. 1952). It is usually used with regard to four-footed, earthly creatures in Leviticus (13:32, 36). Another word for expressing uncleanness is the Hebrew noun "shqts" meaning "detestable thing" or "abominable thing" and used less than 20 times (Holladay 1971). This is frequently used with "water" (vv. 9-12), "winged" (vv. 13-23), and "creeping creatures" (v. 41) in Leviticus. These antonyms are used interchangeable in Deuteronomy's designation of uncleanness (14:10).

Biblically speaking, human beings and most animals are innately clean and other objects are designated as clean. Though innately clean, these can acquire uncleanness and become unclean through contact with a carcass (e.g., Lev. 5:2), bodily emission (15:2-28), leprosy (13:15), clean vessels touching anything unclean (11:35), being in the tent of the dead person (Num. 19:14), and so on (Holladay 1971). This means that cultically what is clean can become unclean. This acquired uncleanness can only be removed by means of some cultic cleansing, enshrined in the stipulated legislation (Lev. 11: 24-28).

Another form of uncleanness is attested to in this legislation. This kind of uncleanness is not acquired. Certain animals can be considered innately unclean (Hasel 2005). As Lev. 11: 2-23 makes clear, these animals have not acquired ritual uncleanness through touching a carcass or any other form of contamination (cf. André and Ringggren 1974). They are all unclean because they do not meet the qualitative distinction described by God. In any case, unclean animals are non-ritually unclean, but innately unclean for food when alive. This concept of uncleanness, as discussed here, forms part of Hebrew legislation with reference to dietary laws.

In the primordial era, the distinction of clean and unclean animals falls within the universal character of Genesis 1-11. The purpose of this distinction, in this setting, is not apparently clear. Noah offered burnt sacrifice of every clean animal and every clean bird to God (Gen. 8:20). The use of clean animals for burnt offering to God has already been glimpsed in Abel's sacrifice (4:4; cf. 22:8, 13). It appears that the unclean animals were not fit for sacrifice, and probably for food, because they were inherently unclean. In the creation account, they were created with divine admiration. Humanly speaking, they may not have been fit for specific functions and uses, yet they were preserved in the flood because they were God's handiworks (Gen. 9: 9-11, 12, 15; Hiers 1996-1998).

\section{Caring for Unclean Animals in Ancient Israel}

The foregoing has shown that unclean animals were part of God's creation, which he deemed satisfactory. The mention of clean and unclean animals in the flood story lacks some qualitative distinction and specific identification. It is rather in the history of Israel that such distinction and representative identification are enumerated. Here, land animals which are cloven-footed and chew the cud should be clean for food. This means that animals with only one of these qualities are considered unclean for food (Lev. 11). In Deuteronomy, the ox, the sheep, the goat, the red deer, the gazelle, the roe deer, the ibex, the addax, the oryx, and the mountain sheep are representative of the edible, while camels, rock badgers, pigs, for example, constitute an 
inedible class of animals (14:4-8; NAB; Baerg 1989). There is no graded uncleanness amongst the unclean animals.

In the pre-history of ancient Israel, the people of God anticipated the caring for of unclean animals. Abram's riches consisted of slaves and four-footed animals. Amongst these animals are donkeys and camels (Gen.12:16; 24:10-11). Rebecca sat on a camel (v. 63). Like his grandfather, Jacob had camels, horses, and donkeys $(32: 7,15)$. Jacob and his family sat on camels (31:17). Unclean animals were used and cared for in this period.

While in Egypt as slaves, the people of Israel had livestock, consisting of horses, donkeys, camels and flocks (Exod. 9:3). These may be representative of the domestic animals of the time. When God struck the livestock of the Egyptians with deadly pestilence, the livestock of the people of Israel were saved (v. 4). The people of Israel insisted on leaving Egypt with their livestock so that they could offer some as sacrifice to the Lord (10:26; cf. 1Es 5:1). As a ritual component of the institution of passover, all the firstborn of their livestock essentially belonged to the Lord, including the unclean (Exod. 13:12). "The unclean shall be redeemed with a sheep or killed” (v.13; Num. 10:36; Brin 1977; Henshke 2001). In the Ten Commandments, each of Israelites is charged not to covert his neighbour's property, including unclean animals (20:17). On the seventh-day Sabbath, every living creature, including unclean animal, in the household of an Israelite must be given rest (v. 10). Just as Israel needs rest, her animals deserve rest and bodily refreshment (Deut. 5:14). Their livestock were with them in their exodus experience (Num. 20:4). When they complained of thirst, God instructed Moses to provide them, as well as their livestock, with water (vv. 8.11). If one finds an entrapped animal of one's enemy, one is obliged to rescue such animal be it clean or unclean (Exod. 23:4-5). God's concern for animals still affirms the "theo-ecocentic" character of Israel's socio-ecology. When they survive, they survive with their livestock and vice versa (1 Macc. 2:20, 38). If Israel obey the ordinances of God, He will not cause sterility and barrenness among them and their livestock (Deut. 7:14; 1 Es. 8:50). Similarly, when they become disobedient, not only do they suffer God's punishment, but also their livestock suffers (Neh. 9:37). It appears ecologically difficult to define the existence of Israel without their livestock and their inseparable relationship to them. Particularly, divine injunctions were obeyed with respect to the caring for the unclean domestic animals and their preservation.

A few examples of such socio-ecological relationship between Israel and unclean animals can be delineated as follows. Achsah, the daughter of Caleb, sat on a donkey (Josh. 15:17-18). Prophet Zachariah’s prophecy about the restoration and blissful happenings in Israel's history reads, "Rejoice greatly, O daughter of Zion! Shout aloud, O daughter of Jerusalem! Lo, your king comes to you; triumphant and victorious is he, humble and riding on a donkey, on a colt, the foal of a don" (9:9, NRS; emphasis is mine). Her Messianic King will sit on a donkey - an animal. This prophecy was later appropriated in the Christ event prior to the crucifixion of Jesus (Matt. 21:1, 5, 7). The Jews in the Old and New Testament, plus the intertestamental periods, used live donkeys (e.g., 1 Sam. 25:20; Matt. 21:2; Sir. 33:25). Like donkeys, camels (e.g., Gen. 12:16; Matt. 19:24; Tob. 9:2, 5) and horses (e.g., 2 Sam. 8:4; Sir. 48:9) were part of the socio-ecological system in these periods. These animals were used in poetic imageries and real life situations.

The dog played a significant role in the socio-ecological economy of ancient Israel. In the HB, the dog is used in both metaphorical and literal senses. Metaphorically, human behaviour (e.g., 1 Sam. 17:43) or one's enemy (Ps. 22:16) is usually likened to that of a dog. This usage would mean that conceptually they knew the behaviour and nature of a dog, in their socio-ecological worldview. Literally speaking, any meat that is 
mangled by a wild beast shall not be eaten, but rather be given to a dog, says the Lord (Exod. 22:31). Even the flesh of the apostate Jeroboam and his cohorts was to be eaten by dogs (1 Kgs. 14:11). In the parable of the rich and Lazarus, dogs lick the sores of Lazarus (Luke 16:21). On his journey to Media, Tobias, the son of Tobit, went with his dog, together with the angel Raphael (Tob. 6:2; 11:4). Here, it is clear that dog is treated as a pet.

The pig was an unclean animal, according to the "kashrut" laws (Price 1925). The pig is used metaphorically and literally. Again, certain human behaviour is depicted metaphorically as that of a pig (Prov. 11:22). Outside the HB, Philo gives an insightful usage: "for which reason the lawgiver, very admirably, compares those of the sophists who live in this manner to the race of swine, who live a life in no respect pure or brilliant, but confused and disorderly, and who are devoted to the basest habits" (Philo "De Agricultura" 1:144). In literal sense, God expressed his displeasure at the people of Israel eating swine flesh (Isa 65:4; 66:17). Archaeological studies suggest that pigs were reared in Palestine in ancient times (Dyson 1953; Lobban 1994; Diener and Robkin 1978; Firmage 2008). Pigs were allowed to roam on the streets (Firmage 2008). It suggests that the community and environment were accommodating to pigs (Derrett 1979; Firmage 2008). Jesus used pigs in His parable of the prodigal son (Luke 15:15; Lobban 1994). In His parabolic narratives, He uses culturally known semiotic values that are imaginative, but real to life experience (Warren 2002). It may be deduced that, while it was abominable to eat the flesh of swine, it was religiously appropriate to care for the live ones in a variety of ways (Bulmer 1989).

\section{Contemporary Application}

The HB does not describe gradation of unclean animals. Philo faithfully adds:

For he says that the pig is an unclean animal, because it divides the hoof and does not chew the cud, just as he has pronounced the camel unclean for the contrary reason because it chews the cud and does not divide the hoof. But as many animals as partake of both these qualities are very appropriately described as clean, because they have avoided impropriety in both the aforementioned particulars. For division without memory, and care, and a diligent examination of what is best, is but an imperfect good; but the combination and union of the two in the same animal is a most perfect good. (Philo "De Agricultura" 1:145)

Philo recognizes that both the camel and the pig are equally and absolutely unclean. His statement does not imply graded uncleanness of camels or the absolute uncleanness of pigs.

The present day religious Jews, some Ethiopian Christians, and the Seventh-day Adventist church mainly still hold on to the "kashruth" law (Nichol, ed. 1976-1980; Blench 2002; Barak-Erez 2007). Swine are not reared among religious Jews in present Israel. Rather, they are found in some Arab-Christian communities and scientifically-researched based environments like kibbutz. Rabbi Shlomo Vilk, the leader of a Jerusalem synagogue, comments that:

The pig, even more than other animals considered non-kosher, has become the symbol of everything that for Jews is "unpure, filthy and dirty". The Romans who destroyed the second Jewish temple in AD 70 had the pig as their emblem, and as a result, Jewish sages also prohibited raising the animals on the land of Israel. It became a symbol of something which Jews don't do... to bring it into the public realm... This is disrespect for so many Jews. (Sharp, "Israeli Pig-Farming Kibbutz Draws Religious Ire” 2010)

Rabbi Vilk's statement suggests that pigs were reared or cared for prior to the destruction of the temple. Yet Vilk (Sharp, 2010) understands that, in principle, he can touch a pig but in practice will not touch it. Of Ethiopian Christians, Roger M. Blench notes: "the Ethiopian Christian church, whose dietary promotions are usually 
based on the Old Testament, also bans the eating of pork and, for this reason, the pigs in Ethiopia are confined to the non-Christian regions in the west of the country" (Blench 2002). This implies that once they are not edible, they should not be cared for. The "Seventh-Day Adventist Bible Commentary" says, "of all animals prohibited by law, swine were considered the most unclean” (see Isa. 65:3, 4; 66:17; Nichol, ed. 1976-1980). It need be mentioned that the apparent harmful effect of the flesh of swine may be a reference point. In any case, this suggests gradation of unclean animals, which may not be supported by the concept of biblical uncleanness of animals.

It may be enlightened to rehearse some salient points to make a contextual application. In the creation story, human beings were to eat seed-bearing plants, while other terrestrial creatures were to eat all green plants (Gen. 1:29-30). This suggests that the human diet had some limitations. Yet, they were charged to care for the Garden of Eden (2:15). In this case, the inedible plants were to be cared for, but not to be hewn. At this stage, flesh eating had not been introduced, yet all animals existed under the rule of humans. Their usefulness did not emerge after the flood. For human survival, certain plants were allowed to be eaten in the pre-flood era and animal flesh was allowed to be eaten in the post-flood era. The usefulness of other creatures to human existence may not have essentially occasioned their continuous existence. Ultimately, every creation on earth, including humans, exists for the Creator’s glory (Exod. 9:29; Exod. 19:5; Deut. 10:14; Ps. 19:2; 24:1; 1 Cor. 10:26). In the context of human stewarding of God's creation, the primordial humans cared for other creatures. The fact that certain plants and animals were not permitted to be used as food did not mean their uselessness in the ecosystem or they were enemies to humanity. If these religious bodies faithfully adhere to kosher law, its meaning and implication should inform their socio-ecological stance towards the unclean animals.

\section{Conclusion}

This study was tasked to determine the place of unclean animals in the socio-ecological economy of ancient Israel. It has been established that humans were charged to be responsible stewards over God's creation, which was deemed by God to be satisfactory and perfect. Unclean animals were created by God too. Unclean animals were innately unclean, because God has said so. By touching or caring for live unclean animals, Israel did not cultically acquire uncleanness. They were unclean for food. Unclean animals were part of the socio-ecological economy of ancient Israel. The understanding of ancient Israel of the "kashruth" made them care for unclean animals, as a divinely ordained requirement, because God, the creator, made and still cares for them.

\section{Works Cited}

André, Gunnel, and Helmer Ringggren. “A Theological Dictionary of the Old Testament.” $t m$ Eds. Botterweck, Gerhard Johannes, and Ringgren Helmer. MI: Eerdmans, 1974.

Baerg, Harry J. Bible Plants and Animals. Vols. 1-2. Washington, DC.: Review and Herald, 1989.

Barak-Erez, Daphne. Outlawed Pigs:Law, Religion, and Culture in Israel. Madison, WI: The U of Wisconsin P, 2007.

Bernstein, Ellen, ed. "Where Nature and Sacred Meet?” Ecology and the Jewish Spirit. Woodstock, Vt.: Jewish Lights, 1998.

Bird, Phyllis Ann. “'Male and Female He Created Them': Genesis 1:27b in Context of the Priestly Act of Creation.” Harvard Theological Review 74.2 (1981): 129-59.

Blench, Roger Marsh. “A History of Pigs in Africa.” The Origins and Development of African Livestock: Archaeology, Genetics, Linguistics and Ethnography. Ed. Roger M. Blench and Kevin C. MacDonald. New York, NY: UCL, 2002.

Brin, Gershon. “The Firstling of Unclean Animals.” The Jewish Quarterly Review 69.1 (1977): 1-15. 
Brown, Francis, Driver Samuel Rolles, and Briggs Charles A. "A Hebrew and English Lexicon of the Old Testament with an Appendix Containing the Biblical Aramaic.” Lexicon of William Gesenius (1952): s.v. “môr," "tame,” rhd.”.

Bulmer, Ralph. "The Uncleanness of the Birds of the Leviticus and Deuteronomy.” Man: Journal of the Royal Anthropological Institute 24 (1989): 304-321.

Derrett, John, and Duncan Martin. “Spirit-Possession and the Gerasene Demoniac.” Man 14. 2 (1979): $286-93$.

Diener, Paul, and Eugene Robkin. "The Search for Cultural Origins: The Question of Islamic Pig Prohibition (Comments and Reply).” Current Anthropology 19. 3 (1978): 493-540.

Douglas, Mary. Purity and Danger: An Analysis of the Concepts of Pollution and Taboo. London: Routledge and Kegan Paul, 1966.

Dyson, Robert H. Jr. “Archaeology and the Domestication of Animals in the Old World.” America Anthropologist 55.5 (1953): 661-673.

Firmage, Edwin. Zoology the Anchor Bible Dictionary. Ed. David Noel Freedman. New York: Yale UP, 2008.

Hasel, Gerhard Franz. Is the Distinction between Clean and Unclean Animals in Leviticus 11 Still Relevant Today? 2005. < http://www. giveshare.org/Health/cleananduncleanhasel.html>

Henshke, David. “A Non-Rabbinic Law Rejected by the Tannaim.” The Jewish Quarterly Review. XCII, 1-2 (2001): 79-103.

Hiers, Richard H. "Reverence for Life and Environmental Ethics in Biblical Law and Covenant.” Journal of Law and Religion 13.1 (1996-1998): 127-188.

Hollayday, W. L. Jr. A Concise Hebrew and Aramaic Lexicon of the OT. Grand Rapids, MI: Eerdmans, 1971.

Josephus, Flavius. The Works of Josephus. Ed. William Whiston. Vol. 4. New York: Oakley Mason, 1860.

Katz, Eric. "Judaism and Ecological Crisis.” Worldviews and Ecology: Religion, Philosophy, and the Environment. Ed. Marry Evelyn Tucker, and John A. Grim. Maryknoll, N.Y.: Orbis, 1994. 55-70.

Lobban, Richard A. Jr. “Pigs and their Prohibition.” International Journal of Middle East Studies 26.1 (1994): 57-75.

Lynn White, Jr. “The Historical Roots of Our Ecological Crisis.” Science 155 (1967): 1205-07.

Milgrom, Jacob. "Ethics and Ritual: The Foundations of Biblical Dietary Laws.” Religion and Law: Biblical-Judaic and Islamic Perspectives. Eds. Edwin B. Firmage, Bernard G. Wies, and John W. Welch. Winona Lake, IN: Eisenbrauns, 1990.

Nash, Roderick. “The Greening of Religion.” This Sacred Earth: Religion, Nature, Environment. Ed. Roger S. Gottlieb. New York: Routledge, 1996. 194-229.

Nichol, Francis David, ed. “The Swine (Lev 11:7).” The Seventh-Day Adventist Bible Commentary. Rev. ed. Washington, DC: Review \& Herald, 1976-80. 1:754.

Rockefeller, Steven Clark. Faith and Community in an Ecological Age, in Spirit and Nature. Ed. Steven Clark. Rockefeller and John C. Elder. Boston: Beacon, 1992.

Schwartz, Eilon. "Judaism and Nature: Theological Moral Issues to Consider While Renegotiating a Jewish Relationship to the Natural World.” Judaism: A Quarterly Journal 44 (1995): 437-47.

Sharp, Heather. Israeli Pig-Farming Kibbutz Draws Religious Ire. <http://news.bbc.co.uk/2/hi/middle_east/8708541.stm>

The Works of Philo. Trans. Charles Duke Yonge. <http://www.earlychristianwritings.com/yonge/1993>

Tirosh-Samuelson, Hava. “Nature in the Sources of Judaism.” Daedalus 130.4 (2001): 99-124.

Vogel, David. “How Green is Judaism? Exploring Jewish Environmental Ethics.” Business Ethics Quarterly 11.2 (2001): 349-63.

Waltke, Bruce K., and M. O’Connor. An Introduction to Biblical Hebrew Syntax. Winona Lake, IN: Eisenbrauns, 1990.

Warren, William F. Jr. Interpreting New Testament Narrative: The Gospels and Acts' Biblical Hermeneutics: A Comprehensive Introduction to Interpreting Scripture. 2nd. ed. Ed. Bruce Corley, Steve W. Lemke, and Grant I. Lovejoy. Nashville, TN: Broadman \& Holman, 2002. 316-330. 